\title{
Enhanced biological degradation of Dextromethorphan and real pharmaceutical wastewater followed by reverse osmosis membrane
}

\author{
Reda A.M. Nassef ${ }^{1}$, Medhat H. Hashem ${ }^{2}$, Ayman M. M. Sawan ${ }^{3}$, Nashwa M. H. Rizk ${ }^{1}$ and Ibrahim \\ E. Mousa ${ }^{1 *}$ \\ ${ }^{1}$ Department of Environmental Biotechnology, Genetic Engineering and Biotechnology Research Institute, \\ University of Sadat City, Menofiya, 22857 Egypt \\ ${ }^{2}$ Department of Animal Biotechnology, Genetic Engineering and Biotechnology Research Institute, \\ University of Sadat City, Menofiya, 22857 Egypt \\ ${ }^{3}$ Chemistry Department, Alghad International Colleges for Applied Medical Sciences, Almadina \\ Almonawarah Saudi Arabia. Permanent address, Ministry of Education, Egypt.
}

*Corresponding author: E-mail: ibrahim23365@yahoo.com

\begin{abstract}
Biological degradation of pharmaceutical wastewater followed by reverse osmosis (RO) membrane technology was investigated. The Membrane separation of Dextromethorphan was performed in a continuous mode operation. Synthetic wastewater was prepared by addition of desired amounts of Dextromethorphan to deionized water. Experiments were performed at room temperature and the $\mathrm{pH}$ correction. The effective operational parameters included $\mathrm{pH}$ correction; contact times, Dextromethorphan concentration and RO were studied consecutively. The effect of mixing various techniques by chemical, biological treatment (aerobic and anaerobic) and physical processes had good opportunity to get more removal\%. The final step was reverse osmosis membrane to remove all suspended and dissolved solids. The efficiency of full treatment plant was $20.9 \%, 99.9 \%, 99.5 \%$ and 93.9\% for $\mathrm{pH}, \mathrm{COD}, \mathrm{TSS}$ and TDS respectively. The produced water could be reused and recycled.
\end{abstract}

Keywords: Pharmaceutical wastewater; Dextromethorphan; Aerobic/anaerobic digestion; Reverse osmosis; metals.

\section{INTRODUCTION}

Pharmaceutical are increasingly utilized for medical applications in humans and animals and are also added to animal feeds in order to prevent the spread of diseases and to promote growth (Nezamzadeh - Ejhieh and Shirzadi, 2014). Commonly used pharmaceutical are divided into different categories based on their chemical structure (Chang et al., 2015). Unfortunately, the misuse of chemical with high potential for contamination of the environment, specially water resources and soil has raised serious concerns due to their high persistent, biological activity, acute and chronic toxicity effect on ecosystems and propagation of resistance in microbes.

Biodegradation efficiency of pharmaceutical pollutants mainly depends on their solubility in wastewater. If the solubility of micro-pollutant is low (hydrophobic compound) then it will be retained in sewage sludge and retention of these compounds in sludge provides more time for microbial degradation 
(Zhao et al., 2013). Micro pollutant get degraded either by catabolic microbial enzymes or utilized by microorganisms as a carbon source (Cherik and Louhab 2015).

High consumption of pharmaceuticals led to concomitant concern observing its presence in the environment because a large proportion of these therapeutic compounds cannot be assimilated and metabolized by the human body, thus excreted via feces and urine and enters into municipal wastewater treatment plant (WWTP). The main constituents of pharmaceutical waste are antibiotics, chemotherapy products, hormones, analgesic, antipyretic and antidepressants. Many studies revealed that the presence of various pharmaceutical in the aquatic environment (Ferrando-Climent et al., 2014).

The acidity and alkalinity correction in wastewater treatment plant may have an effect on the nature of pharmaceutical pollutant and also influences the microbial community structure and increase or decrease microbial enzyme activity. Kim et al. (2014) reported the presence of clarithromycin, metformin, atenolol, carbamazepine, and trimethoprim at high concentrations (>500 ng/L) in the effluent of membrane bioreactor WWTP. The environmental concentrations of antibiotics, antidepressants, chemotherapy products, analgesic compounds, hormones and lipid regulators range from 0.04 to $6.3 \mathrm{lg} / \mathrm{L}$ (Jones et al., 2001).

Forward osmosis is an emerging technology used in water reuse and desalination [McCutcheon et al., 2006; Holloway et al., 2007; Wang et al., 2007; Cornelissen et al., 2008]. It is regarded as a natural process that utilizes osmotic pressure gradient to draw the water from the dissolved solutes in feed solution across a semipermeable membrane [Pearce, 2010; Jin et al., 2012; Hancock et al., 2012]. Among the other RO pre-treatments, FO has much lower fouling tendency and can operate over a longer period of time without cleaning [Zaviska et al., 2015]. Increasing interest in FO is fueled by the global demand for less fouling, high recovery and low energy consuming process increasing lifespan of the membrane compared to the pressuredriven membrane process [Cath et al., 2005; Cath et al., 2006].

This study aimed to evaluate the removal efficiency of all insoluble component and decreasing pharmaceutical compounds.Detection of the removal percentage and comparison to Egyptian guidelines were investigated. Different methods were used for wastewater treatment arranged between conventionally treated methods (physical, Chemical and biological) and new technology (Reversal Osmosis technology) was implemented for Dextromethorphan degradation. Real pharmaceutical wastewater was treated through proposed technologies. The effectiveness of this system was verified by observing the effluent content such as microbial load during an operation periods, total element content (ICP-MS), biological oxygen demand (BOD), chemical oxygen demand (COD), total suspended Solids (TSS), $\mathrm{pH}$ and total dissolved solids (TDS). 


\section{MATERIALS AND METHODS}

The design of the proposed system had two separately draining systems. One separated draining network specified for industrial sewage and the other is separated for domestic network. Finally, industrial sewage was collected in sewage treatment chambers. The first chamber was used for equalization and adjusting the $\mathrm{pH}$ value through automatic control chemical dosing system. Second chamber was used for increasing the retention time for good mixing after dosing system. The key stage for removal excess after biological and chemical treatment was Reversal Osmosis (RO) membrane. After using method for treatment above, the cost reduction of wastewater remediation was estimated.

\section{Experimental setup}

A reactor with the total volume of $800 \mathrm{~mL}$ (height of $15 \mathrm{~cm}$ and inner diameter of $6 \mathrm{~cm}$ ) was used for conducting the experiments. The wastewater source used was installed above the reactor with a distance of 4 $\mathrm{cm}$ from the reactor edge. The reactor contents were mixed using a magnet stirrer at $150 \mathrm{rpm}$. For each experimental run $100 \mathrm{~mL}$ of solution was introduced to the bioreactor (anaerobic and aerobic).

\section{Membrane separation}

Reverse Osmosis (RO) was simulated using ROSA 9 software, that mimic the original RO system. This system is obtainable from shelf in a number of retails countrywide with The FILMTECTM Membranes system. The Membrane separation of Dextromethorphan was performed in a continuous mode operation. Synthetic wastewater was prepared by addition of desired amounts of Dextromethorphan to deionized water.
Experiments were performed at room temperature and the $\mathrm{pH}$ of the solution was adjusted by addition of $1 \mathrm{~N} \mathrm{HCl}$ and/or $1 \mathrm{~N}$ $\mathrm{NaOH}$. Effect of operational parameters including w (0.5-10), initial pH (3-11), working solution of Dextromethorphan dosage(0.1-0.4 $\mathrm{g} / \mathrm{L})$, irradiation time $(0-120 \mathrm{~min})$ and total phenolic concentration $(0.5-30 \mathrm{mg} / \mathrm{L})$ were studied consecutively. The effect of membrane adsorption was studied in absence of biological operation in selected conditions. In addition, in order to evaluate the feasibility of repetitive use of biological/RO, four cycles of treatments were carried out in selected conditions.

\section{Analytical methods}

HPCL detection for Dextromethorphan $\mathrm{HBr}$ was used. Detection wavelength was 203 $\mathrm{nm}$ and the Column temperature was $25 \mathrm{OC}$. The flow rate of mobile phase was $1 \mathrm{ml} /$ minute. Standard preparation of Dextromethorphan $\mathrm{HBr}$ stock was prepared. Accurately weighed $22.5 \mathrm{mg}$ of Dextromethorphan $\mathrm{HBr}$ were transferred to 50 $\mathrm{ml}$ volumetric flask as working standard. The solution was dissolved in and complete to volume with mobile phase then sonicated for 10 minutes. Accurately measured $10 \mathrm{ml}$ of this solution was transferred to $50 \mathrm{ml}$ volumetric flask, dissolved in and complete to volume with mobile phase. The retention time for tetracycline was $5.97 \mathrm{~min}$. The tetracycline removal was determined using Eq. (1):

Removal\%=Co-Ct/Co $\times 100$

where $\mathrm{CO}$ and $\mathrm{Ct}$ are the concentrations of Dextromethorphan before and after the Biological/RO reaction, respectively (Mousa, 2016). 


\section{Characterization of aqueous samples}

Real pharmaceutical samples were supplied by Liptis Egypt (6 $6^{\text {th }}$ October; Egypt). Water analyses were carried out by total dissolved solids (TDS) that was determined experimentally according to ASTM D-1888. Conductivity and resistivity were determined according to ASTM D-1125. $\mathrm{pH}$ was determined experimentally according to ASTM D-1293. Salinity value was calculated upon chloride content value. Cations and anions were determined experimentally according to ASTMD-4327 using Dionex ICmodeIDX1100 equipped with high capacity columns. Alkaline species $(\mathrm{CO} 3, \mathrm{OH}$, and $\mathrm{HCO} 3)$ were determined experimentally according to ASTM D-3875. BOD5 was determined after incubation for 5 days in tightly stoppered bottles in the dark at $20^{\circ} \mathrm{C}$ and determining the oxygen consumed. Conductivities were measured at $25{ }^{\circ} \mathrm{C}$ directly in $\mathrm{mS} / \mathrm{cm}$ using a digital conductivity meter. Finally, the fine metals were detected through ICP-MS methods (SM-1325-ICP-MS) according to APHA (2005).

\section{Data analysis}

Graphs and chats were constructed using MS office Excel version 2013 and Statistical for Social Sciences version 17 software was used in the analysis (SAS, 2007). $95 \%$ level of significance was used as the critical point $(P=<0.05)$. The collected data on the physic-chemical parameters, density of indicator were appropriately subjected to statistical analysis to find their corresponding mean variations and was performed according to Steel and Torrie (1980).

\section{RESULTS AND DISCUSSION}

The real wastewater resulted from soda ash treatment was subjected to a biological treatment. The inlet $\mathrm{pH}$ was 11 and it was reduced to 7 by adding $\mathrm{HCl}$ and the results of corrected $\mathrm{pH}$ was shown in Figure (1) and hence leading to an increase in $\mathrm{Cl}$ and TDS. The water had high levels of $\mathrm{Na}$ ions which were higher than the required standard as shown in Table (1).Biological digestion evaluation

Activated microbes are a widely used aerobic method of wastewater treatment. The waste stream is brought to an aeration tank.
The dissolved oxygen of initial was $<3.5 \mathrm{mg} / \mathrm{L}$ and there are mechanical stirring which provides extra aeration of the waste. Sludge from a previous run is usually reintroduced to the tanks to provide microorganisms. During the period in the aeration tank, large developments of heterotrophic organisms occur. In the activated sludge tank the bacteria occur in free suspension and as aggregates or flocks (Masindia et al., 2017). 
Table 1.Monitoring program for raw pharmaceutical wastewater before mixing:

\begin{tabular}{|c|c|c|c|c|}
\hline Parameter & unit & $\begin{array}{c}\text { Average } \\
\text { value }\end{array}$ & $\begin{array}{c}\text { stander } \\
\text { deviation }\end{array}$ & $\begin{array}{c}\text { Act\# } \\
44 / 2000^{* *}\end{array}$ \\
\hline $\mathrm{pH}$ & & 8.09 & 0.37 & $6.5-9.5$ \\
\hline $\mathrm{BOD}$ & $\mathrm{mg} / \mathrm{l}$ & 875 & 247.49 & 600 \\
\hline $\mathrm{COD}$ & $\mathrm{mg} / \mathrm{l}$ & 1585 & 49.50 & 1100 \\
\hline $\mathrm{TSS}$ & $\mathrm{mg} / \mathrm{l}$ & 325 & 106.07 & 800 \\
\hline $\mathrm{O} \& G^{*}$ & $\mathrm{mg} / \mathrm{l}$ & 19 & 1.41 & 100 \\
\hline $\mathrm{TN}$ & $\mathrm{mg} / \mathrm{l}$ & 28.5 & 16.26 & 100 \\
\hline $\mathrm{TP}$ & $\mathrm{mg} / \mathrm{l}$ & 18 & 2.83 & 25 \\
\hline $\mathrm{TPh}$ & $\mathrm{mg} / \mathrm{l}$ & 0.179 & 0.24 & 0.05 \\
\hline $\mathrm{H}_{2} \mathrm{~S}$ & $\mathrm{mg} / \mathrm{l}$ & 12.5 & 14.85 & 10 \\
\hline $\mathrm{BOD} / \mathrm{COD}$ & $\begin{array}{c}\text { Biological } \\
\text { viability }\end{array}$ & 0.55 & 0.14 & \\
\hline
\end{tabular}

* Oil and grease

** Egyptian guidelines (44/2000)

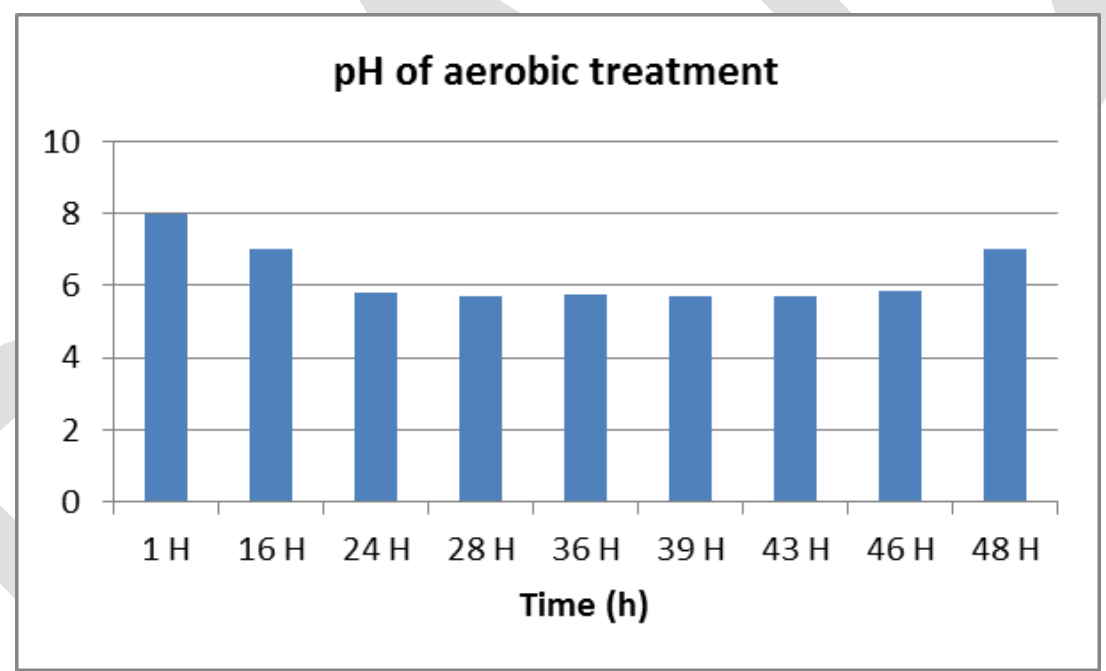

Figure 1. The effect of aerobic condition on the $\mathrm{pH}$ value during treatment for $48 \mathrm{~h}$ period.

Extensive microbial metabolism of organic compounds in the sewage results in the production of new microbial biomass. The results of $\mathrm{pH}$ correction were the most suitable for existence biomass which becomes associated with flocks that can be removed from suspension by settling (Figure 2). $\mathrm{Ng}$ et al.
(2015) evaluated microbial communities in aerobic and Anaerobic performance for treating wastewater from a pharmaceutical factory in a lab scale and demonstrated a positive influence of halophilic organisms on the treatment efficiency. 


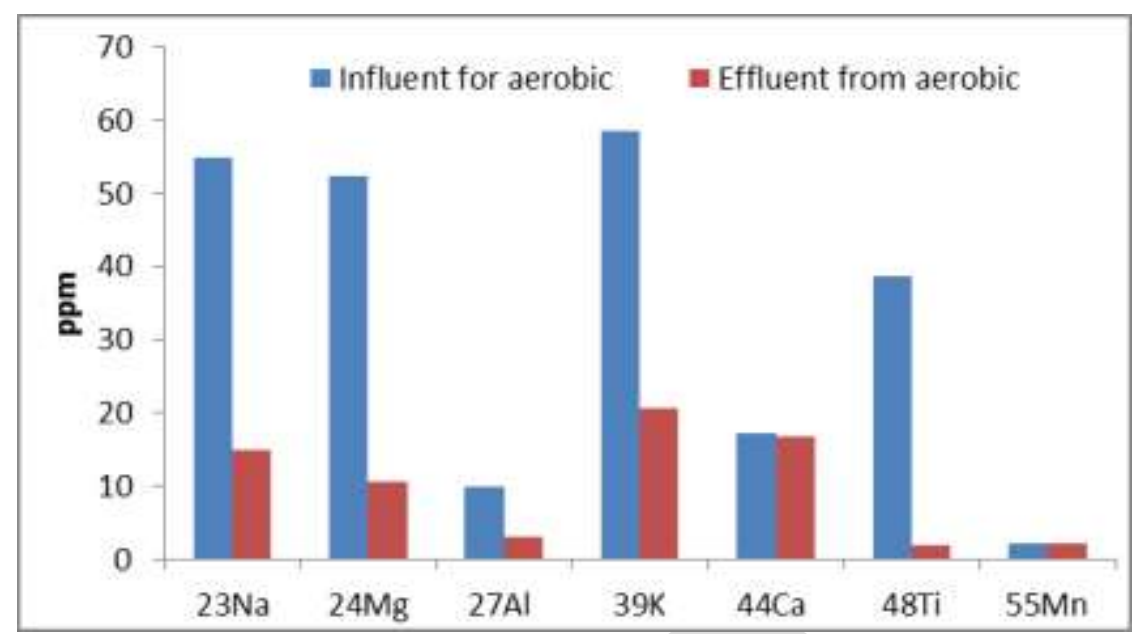

Figure 2.Comparison between concentration of different element before and after treatment pharmaceutical wastewater by sludge aerobic conditions.

The effect of sludge through aerobic condition on elements content concentration values during treatment pharmaceutical wastewater in aerobic treatment. Under aerobic conditions, determined the concentration of different element before and after treatment pharmaceutical wastewater after add sludge figure (2). There were significant reductions in all elements with average range $12 \%$ to $67 \%$ as a result of aerobic digestion and floc sedimentation.

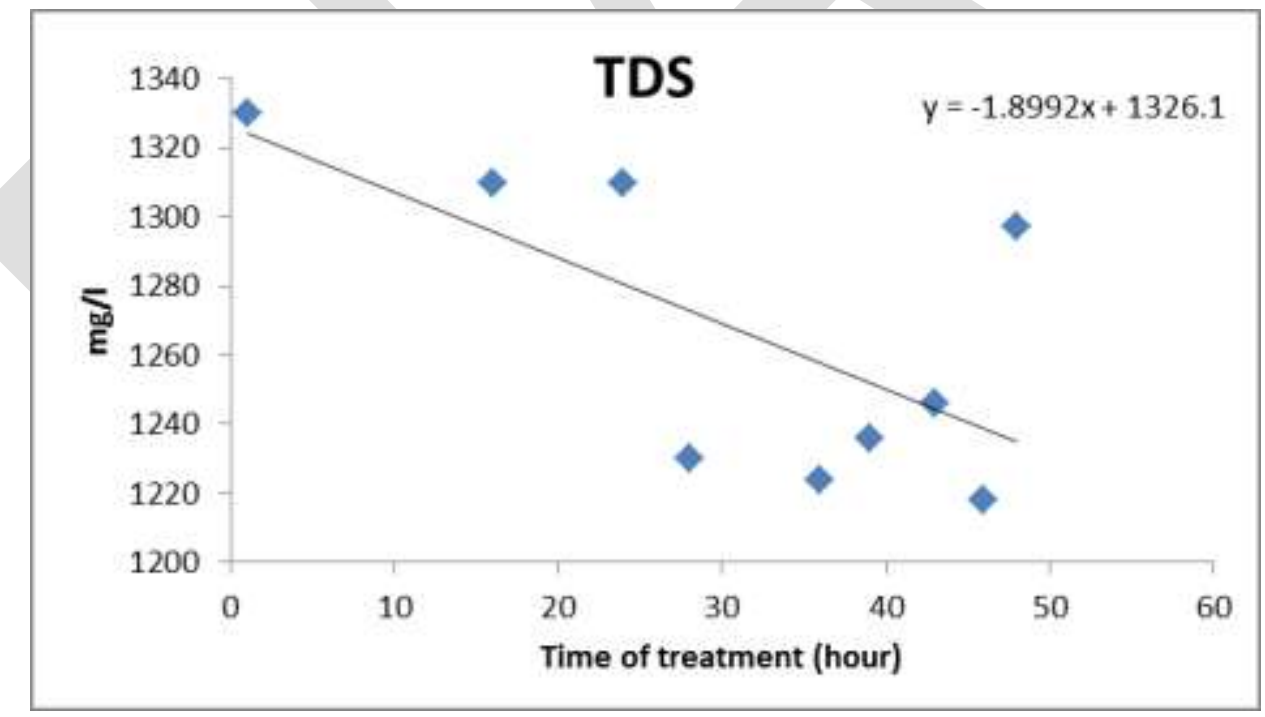

Figure 3.The effect of aerobic sludge on TDS values during treatment of effluent anaerobic treatment step.

The effect of sludge through aerobic condition on TDS content during treatment pharmaceutical wastewater in aerobic treatment was shown in Figure (3). Under aerobic conditions, determined the concentration of different element before and after treatment pharmaceutical wastewater after mixing with receiving sludge was monitored. The removal of ionizable compounds such as Dextromethorphan greatly depends on $\mathrm{pH}$ for degradation. In acidic condition, these compounds exhibit hydrophobic form that results in higher elimination. However, the removal of non 
ionizable compounds like carbamazepine is Membrane separation evaluation

Reverse osmosis (RO) implication for the production of recycled water was used. The simulated Reverse Osmosis (RO) technology was applied to resultant water. The main aim was to recover water that meets the Egyptian guidelines. According to Figure (2b), the value for TDS was linear decreased

(a)

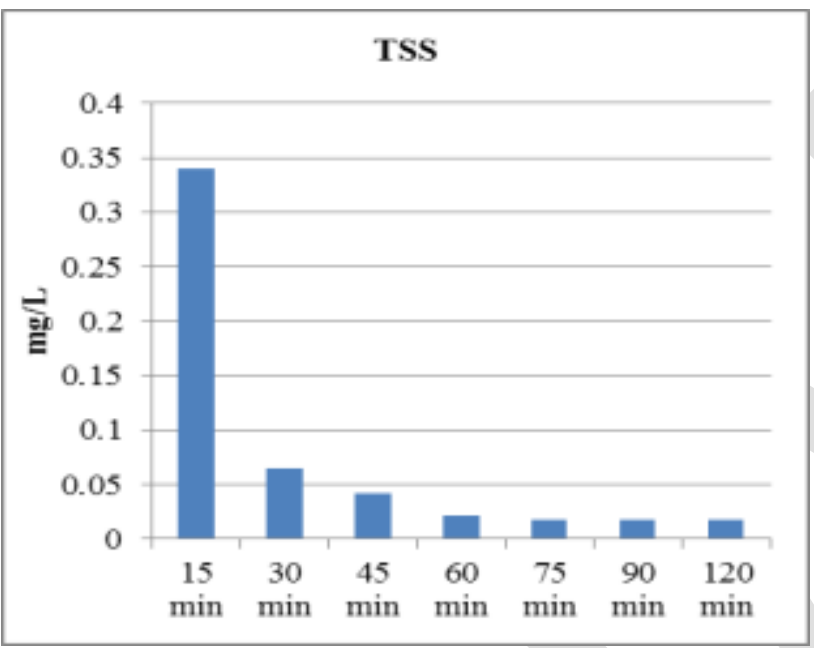

independent of $\mathrm{pH}$ (Castiglioni et al., 2006).

and fixed in at $200 \mathrm{ppm}$, so this water can be used for cleaning in different places in side plants, and decreased the amount of water used from city water and cost reduction for water in side plant the efficiency for $\mathrm{RO}$ membrane and the recovery for $\mathrm{RO}$ system from $68 \%-79 \%$ during this experimental.

(b)

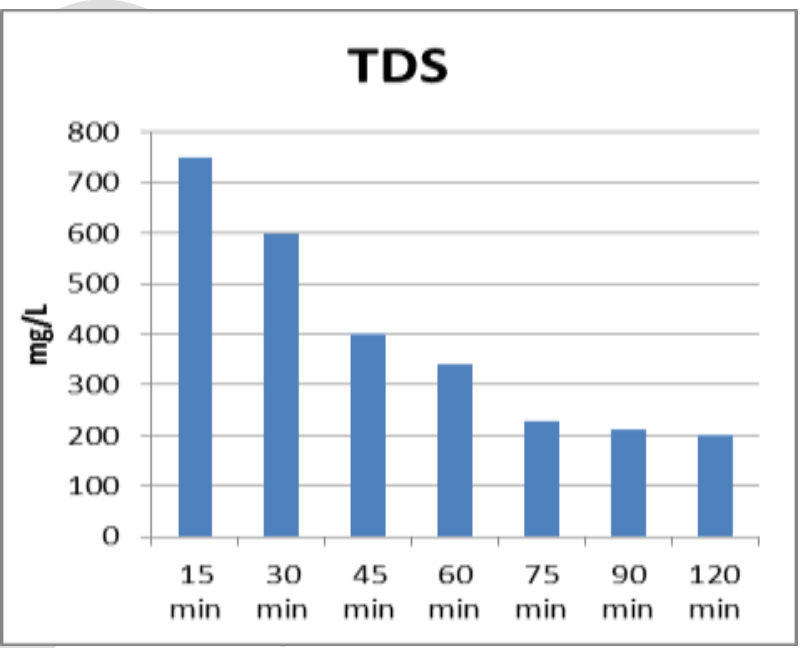

Figure 4.Characteristic for TSS (a) and TDS (b) from RO water produced in last stage.

According to Figure (5), the different between the influent pharmaceuticals wastewater and effluent after last stage (RO).the value for all metal content go to minimum value which has city water properties this meaning the physical treatment was more active in this case.

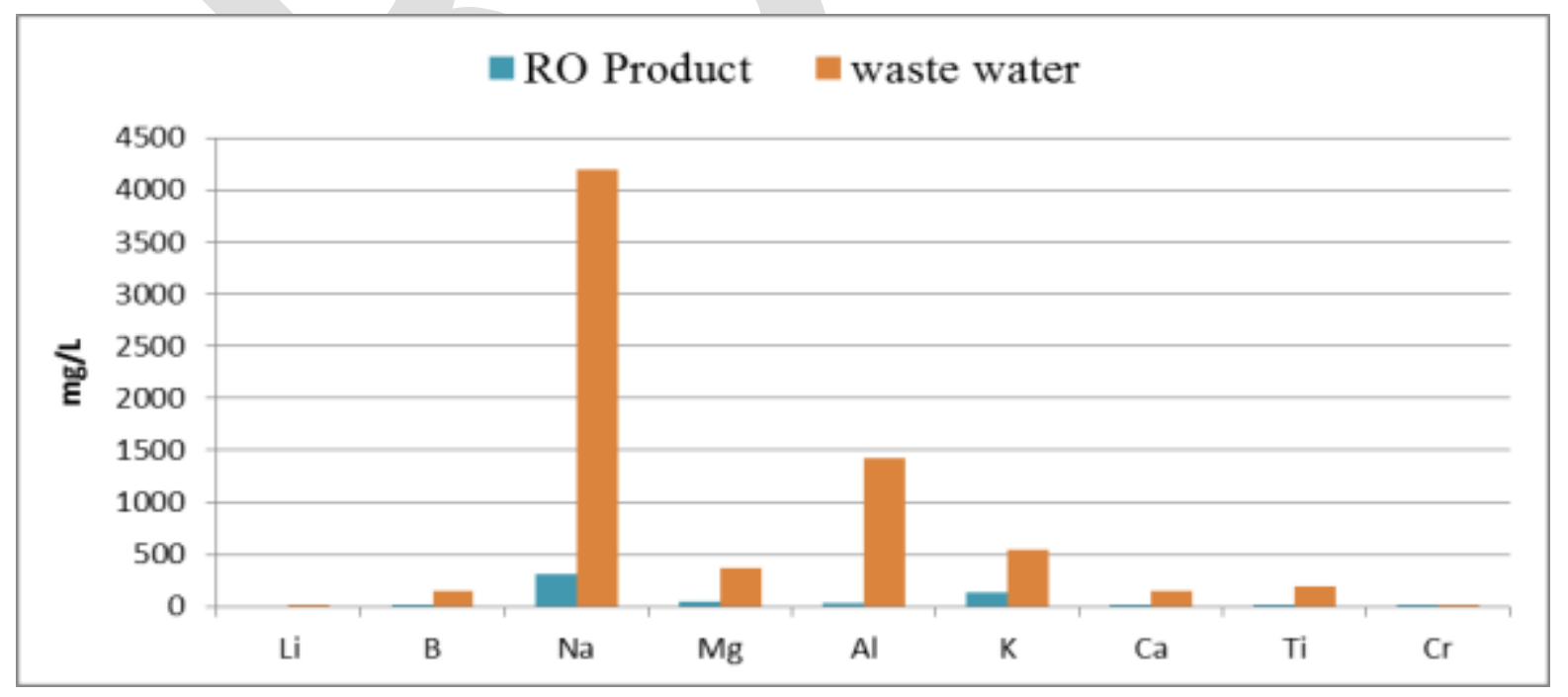

Figure 5.comparison between real pharmaceutical waste water before and after using RO system as post treatment. 
After using $\mathrm{RO}$ simulation software to mimic the behavior of an RO system and to upgrade the quality of water originating from biological stage, lime and soda ash treatment processes. The principal aim was to treat the resultant water to meet the required quality guidelines. The level of $\mathrm{Na}$ was reduced from 4278 to 219 $\mathrm{mg} / \mathrm{L}$ in the $\mathrm{RO}$ treated water. This is an indication that $\mathrm{Na}$ ions were rejected by the $\mathrm{RO}$ system to the brine stream.

Compared to conventional post-treatment technologies, membrane technologies were found to be more cost effective and give better results by removing the particles having size greater than the pore size of the membrane. This results in low silt density index (SDI) value, which makes them more attractive treatment technologies for the water having high total dissolved solids (TDS). Among membrane processes, micro-filtration (MF) and ultra-filtration (UF) are the technologies that have gained global acceptance as suitable pre-treatment technologies for saline water (Khanzadaet al., 2017).

\section{CONCLUSION}

From this study, the feasibility of producing recyclable wastewater and the recovery of valuable minerals from pharmaceutical was investigated. Neutralization of drainage and reduction of metals were done at 120 min of mixing 1: 100 $\mathrm{mg} / \mathrm{L}$ for $\mathrm{HCl}$. Reverse Osmosis was successfully used to purify the resultant water to meet the Egyptian quality standards. The treatment processes showed the following characteristics:

1. Acid neutralization decreased the $\mathrm{pH}$ of influent to $<8$.

2. The biological methods using for controlling on hazard contaminates by bioremediation or by degradation according different hazard.

3. RO succeeded to remove more than 95 of existence $\mathrm{Na}$ in wastewater.

\section{ACKNOWLEDGMENT}

This work was supported by funding from STDF, Egypt (Grant \# 2741). The authors wish to express their sincere gratitude to the Council for Scientific and Industrial research in University of Sadat city for providing lab space
4. The efficiency of full treatment plant was $20.9 \%, 99.9 \%, 99.5 \%$ and $93.9 \%$ for $\mathrm{pH}, \mathrm{COD}, \mathrm{TSS}$ and TDS respectively.

5. The Full system had purified the product water to meet the Egyptian specifications as $44 / 2000$ water quality standards.

The developed treatment process was successfully used to recover real wastewater and valuable products from pharmaceutical industry. Due to the commercial value of the recovered products, the recycling of this resource may results in the recovery of some costs of the treatment process. However, it can be recommended that the rejected stream be used to another facility thus, making this technology sustainable. monetary value hence off-setting the running

to execute this research work. The authors are grateful to Professor Akram Alshawabkeh (Civil and Environmental Engineering Department, Northeastern University, Boston, MA, USA) for helping biochemical/RO reactor. 


\section{REFERENCES}

APHA (American Public Health

Association), (2005). Standard Methods for the Examination of Water and Wastewater. 22 ${ }^{\text {nd }}$ ed. American Public Health Association, Washington, D.C.

Castiglioni, S., Bagnati, R., Fanelli, R., Pomati, F., Calamari, D., Zuccato, E., (2006). Removal of pharmaceuticals in sewage treatment plants in Italy. Environ. Sci. Technol. 40 (1), 357-363.

Cath, T. Childress, A. Elimelech, M. (2006) Forward osmosis: principles, applications, and recent developments, J. Membr. Sci. 281 (1-2) 70-87.

Cath, T.Y. Adams, D. Childress, A.E. (2005) Membrane contactor processes for wastewater reclamation in space, $\mathrm{J}$. Membr. Sci. 257 (1-2) 111-119.

Chang, P.H., Jiang, W.T., Li, Z., Jean, J.S., Kuo, C.-Y., (2015). Antibiotic tetracycline in the environments:a review. J. Pharm. Anal. 4, 86-111.

Cherik, D., Louhab, K., (2015). Biodegradation of diclofenac: a review. Res. J. Chem. Environ. 19 (10), 40-45.

Cornelissen, E. Harmsen, D. Dekorte, K. Ruiken, C. Qin, J. Oo, H. Wessels, L. (2008) Membrane fouling and process performance of forward osmosismembranes on activated sludge, J. Membr. Sci. 319 (1-2) 158-168.

Ferrando-Climent, L., Rodriguez-Mozaz, S., Barceló, D., (2014). Incidence of anticancer drugs in an aquatic urban system: from hospital effluents through urban wastewater to natural environment. Environ. Pollut. 193, 216-223.

Hancock, N.T. Black, N.D. Cath, T.Y. (2012)

A comparative life cycle assessment of hybrid osmotic dilution desalination and established seawater desalination and wastewater reclamation processes, Water Res. 46 (4) 1145-1154.

Holloway, R.W. Childress, A.E. Dennett, K.E. Cath, T.Y. (2007). Forward osmosis for concentration of anaerobic digester centrate, Water Res. 41 (17) 4005-4014.

Jin, X. She, Q. Ang, X. Tang, C.Y. (2012) Removal of boron and arsenic by forward osmosis membrane: influence of membrane orientation and organic fouling, J. Membr. Sci. 389; 182-187.

Jones, O.A.H., Voulvoulis, N., Lester, J.N., (2001). Human pharmaceuticals in the aquatic environment a review. Environ. Technol. 22 (12), 13831394.

Khanzada, N.K. Jamal Khan, S Davies, P.A. (2017) Performance evaluation of reverse osmosis $(\mathrm{RO})$ pre-treatment technologies for in-land brackish water treatment. Desalination 406: 44-50.

Kim, M., Guerra, P., Shah, A., Parsa, M., Alaee, M., Smyth, S.A., (2014). Removal of pharmaceuticals and personal care products in a membrane bioreactor wastewater 
treatment plant. Water Sci. Technol. 69 (11), 2221-2229.

Masindia, V. Osmana, M.S. Abu-Mahfouza, A.M. (2017) Integrated treatment of acid mine drainage using BOF slag, lime/soda ash. Desalination 424: 4552.

McCutcheon, J.R. McGinnis, R.L. Elimelech, M. (2006). Desalination by ammonia-carbon dioxide forward osmosis: influence of draw and feed solution concentrations on process performance, J. Membr. Sci. 278 (12) $114-123$.

Mousa, I.E. (2016) Total petroleum hydrocarbon degradation by hybrid electrobiochemical reactor in oilfield produced water. Marine Pollution Bulletin 109: 356-360.

Nezamzadeh-Ejhieh, A., Shirzadi, A., 2014. Enhancement of the photocatalytic activity of Ferrous Oxide by doping onto the nano-clinoptilolite particles towards photodegradation of tetracycline. Chemosphere 107, 136144.

Ng, K.K., Shi, X., Tang, M.K.Y., Ng, H.Y., (2014). A novel application of anaerobic bioentrapped membrane reactor for the treatment of chemical synthesis-based pharmaceutical wastewater. Sep. Purif. Technol. 132, 634-643. http://dx.doi. org/10.1016/j.seppur.2014.06.021.

Pearce, G. (2010) SWRO pre-treatment: markets and experience, Filtr. Sep. 47 (4) 30-33.

Wang, K.Y. Chung, T.-S. Qin, J.-J. (2007) Polybenzimidazole nanofiltration hollow fiber membranes applied in forward osmosis process, J. Membr. Sci. 300 (1-2) 6-12.

Zaviska, F. Chun, Y. Heran, M. Zou, L. (2015) Using FO as pre-treatment of $\mathrm{RO}$ for high scaling potential brackish water: energy and performance optimisation, J. Membr. Sci. 492: 430-438.

Zhao, D., Yang, X., Chen, C., Wang, X., (2013). Enhanced photocatalytic degradation of methylene blue on multiwalled carbon nanotubese $\mathrm{TiO}_{2}$. J. Colloid Interface Sci. 398, 234239. 